\title{
Quality assessment of drinking water of Multan city, Pakistan in context with Arsenic and Fluoride and use of Iron nanoparticle doped kitchen waste charcoal as a potential adsorbent for their combined removal
}

\author{
Iris Earnest ${ }^{1} \cdot$ Rabia Nazir $^{2} \cdot$ Almas Hamid $^{1}$
}

Received: 5 February 2021 / Accepted: 26 October 2021 / Published online: 8 November 2021

(c) The Author(s) 2021

\begin{abstract}
In majority cities of Pakistan, ground water is the main source of drinking water supply in the taps. Studies from different areas of Pakistan reported the presence of arsenic $\left(\mathrm{As}^{3 / 5+}\right)$ and fluoride $\left(\mathrm{F}^{-}\right)$in drinking water supplies and can be envisaged as a deep-rooted cause of daily exposure of these in humans. The present study was planned with three way approach, i.e., to assess drinking water quality in Multan city, a highly populated and industrial activity area; synthesis of nano-adsorbent for simultaneous, effective and low-cost removal of fluoride and arsenic and manage waste by utilization of kitchen waste for synthesis of the nano-adsorbent. Out of 30 samples collected, $80 \%$ and $73 \%$ samples were found exceeding maximum residual limits (MRL) for $\mathrm{F}^{-}$and $\mathrm{As}^{3 / 5+}$, respectively, while 53\% samples had both $\mathrm{As}^{3 / 5+}$ and $\mathrm{F}^{-}$concentrations greater than MRL. All these water samples were then treated with prepared nano-adsorbent, i.e., iron nanoparticles doped kitchen waste charcoal after evaluating the optimized experimental parameters and application of adsorption, kinetics and thermodynamic models. The nano-adsorbent showed high removal efficacy $81-100 \%$ for $\mathrm{F}^{-}$and $13-100 \%$ for $\mathrm{As}^{3+}$.
\end{abstract}

Keywords Fe/Charcoal nanocomposite $\cdot$ Water quality $\cdot$ Treatment $\cdot$ Arsenic $\cdot$ Fluoride $\cdot$ Kinetics

\section{Introduction}

Water contamination is a global issue; in spite of improved access to clean and quality drinking water, there are still issues in developing countries which are struggling for provision of safe drinking water to their residents (Ritchie and Roser 2018). Arsenic (As) and fluoride (F) are among the major inorganic contaminants in water which, according to WHO, enter into water from both naturogenic (i.e., dissolution of rocks) and anthropogenic sources (industrial effluents). Arsenic is frequently used in synthesis of alloys, wood preservatives, pesticides as well as an ingredient in processing of textiles, pigments, leather, etc. (WHO 2011) Fluoride is used in production of aluminum, steel, glass, fertilizers,

Almas Hamid

almas209@yahoo.com

1 Department of Environmental Sciences, Kinnaird College for Women, 93, Jail Road, Lahore 54000, Pakistan

2 Applied Chemistry Research Center, PCSIR Labs Complex, Ferozepur Road, Lahore, Pakistan etc., and is also used as major ingredient in municipal water fluoridation schemes (WHO 2004). Both contaminants are known to cause number of diseases independently as well as in combination (Jiang et al. 2014; Zeng et al. 2014). Due to their potential adverse health implications, even a low concentration of As and $\mathrm{F}^{-}$in drinking water is detrimental. Arsenic is mostly present as As (III) and in well oxygenated waters as As (V) while $\mathrm{F}^{-}$occurs as inorganic ion (Tang et al. 2010). Several treatment methods have been proposed for removal of $\mathrm{As}^{3+}$ and $\mathrm{F}^{-}$from water such as biological treatment processes, precipitation, ion exchange, nanofiltration, electrodialysis, reverse osmosis, adsorption, etc. (Jagtap et al. 2012).

Various countries, including Pakistan, have reported cocontamination issues of ground water (Guo et al. 2014). According to World health organization (WHO), the permissible limits for As and $\mathrm{F}^{-}$in drinking water is $0.01 \mathrm{mg}$ $\mathrm{L}^{-1}$ and $1.5 \mathrm{mg} \mathrm{L}^{-1}$, respectively, (WHO 2017). In Pakistan, shallow as well as deep aquifer of Punjab were observed to be polluted with $\mathrm{F}^{-}$and $\mathrm{As}^{3 / 5+}$ (Farooqi et al. 2007). The major reasons were attributed to anthropogenic sources, 
i.e., fertilizers, coal combustion and industrial waste leading to their deposition in soil followed by leaching into water resources (Farooqi et al. 2009). Higher levels were also present in surface/ irrigated water of Nagarparkar, Pakistan area which approached levels ranging between 3.6 and $6.8 \mathrm{mg} \mathrm{L}^{-1}$ for $\mathrm{F}^{-}$and $18.5-35.4 \mathrm{mg} \mathrm{L}^{-1}$ for total As (Brahman et al. 2014). Similarly in Sindh, Pakistan, Arsenic levels were 2.6-230 folds higher than the WHO permissible limit for drinking water in Tharparkar area while up to 13 fold higher levels were reported in Khairpur Mir (Qasim and Jakhrani 2018). Elevated As level were also reported in Gujranwala (Mazhar et al. 2019) and Tehsil Mailsi Punjab, Pakistan (Rasool et al. 2016). With escalating industrial activity and infrastructure development these levels are expected to rise significantly. Furthermore, these high levels in drinking water become the major and potential source of exposure of As and $\mathrm{F}^{-}$to both flora and fauna. Humans, being at the top of the food chain, are facing both direct and indirect exposure risk to contaminated water resources and hence, a potential risk of suffering from arsenicosis and fluorosis with increasing level of severity for older age group population to younger children falling in ages of 7-15 years (Brahman et al. 2014).

To look into another perspective, these high levels of both $\mathrm{As}^{3+}$ and $\mathrm{F}^{-}$have raised many questions to the efficacy of current water treatment plants and practices. Considering the low income and developing nature of the country several low-cost water remediation approaches have been followed, i.e., ion exchange, filtration and adsorption using activated alumina, clays and other adsorbents but these face limitations such as applying stringent operating parameters and low efficacy (Malik et al. 2009). With the decreasing levels of allowable limits of contaminants and environmental laws becoming more rigid, the need is to shift to new adsorbents especially that can help in cleaner production and environmental waste management. Nano-adsorbents derived by use of waste materials can offer added advantage owing to high efficiency (due to their high surface to volume ratio) and greater affinity toward both cationic and anionic inorganic pollutants leading to one-step water treatment applications.

Currently, the list of available adsorbents for simultaneous removal of $\mathrm{As}^{3+}$ and $\mathrm{F}^{-}$is very less and the ones available have shown very low to intermediate adsorption capacities, especially for As, and require much longer contact times (Table 1) hindering their prospective for being the material of choice. Hence, there is dire need to design such an adsorbent that can remove both contaminants effectively, in lesser time while exhibiting high adsorption rates as well as capacity. With this objective the nano-adsorbent based on utilization of waste material was designed in order to effectually address the issues of water treatment and waste management. The term Kitchen waste (KW) refers to leftover organic matter from household, restaurants and hotels (Li et al. 2009). It contains several substances of which the major component is food waste which also constitute highest proportion ( $>50 \%$ ) of total municipal waste generated in Pakistan. Although KW, being rich in organic and water content, can be successfully managed through methods such as composting, anaerobic digestion, biofuel production and animal feed yet it is usually dumped in landfills (Korai et al. 2020; Yu and Li 2020).

Therefore, the current research was designed to address the above mentioned problems that are in one way or other interconnected with each other. The study was conducted with three main objectives, i.e., (1) quality assessment of Multan city drinking water in context of $\mathrm{As}^{3 / 5+}$ and $\mathrm{F}^{-}$levels; (2) Synthesis of nano-adsorbent for simultaneous, effective and low-cost removal of $\mathrm{F}^{-}$and $\mathrm{As}^{3 / 5+}$, and (3) Determination of adsorption efficacy of prepared nano-adsorbent in treatment of contaminated actual water samples.

\section{Experimental}

All the solutions employed in the study were prepared using double distilled water and after confirmation of its quality with respect to the absence of $\mathrm{F}^{-}$and $\mathrm{As}^{3+}$. Analytical
Table 1 Adsorption capacities and time required for combined removal of arsenic and fluoride using already reported adsorbents

\begin{tabular}{|c|c|c|c|c|c|}
\hline \multirow[t]{2}{*}{ Adsorbent } & \multicolumn{2}{|c|}{$\begin{array}{l}\text { Adsorption } \\
\text { capacity } \\
(\mathrm{mg} / \mathrm{g})\end{array}$} & \multicolumn{2}{|c|}{ Equilibrium time } & \multirow[t]{2}{*}{ Ref. } \\
\hline & As & $\mathrm{F}$ & As & $\mathrm{F}$ & \\
\hline Goethite (not nano) & 10.1 & 0.5 & $10 \mathrm{~min}$ & $10 \mathrm{~min}$ & (Tang et al. 2010) \\
\hline $\begin{array}{l}\mathrm{Al} \text { - and Fe-doped micro- and nano-sized } \\
\text { polymeric adsorbents }(100 \mathrm{~nm})\end{array}$ & 40.0 & 100.0 & $6-8 \mathrm{~h}$ & $6-8 \mathrm{~h}$ & (Kumar et al. 2011) \\
\hline Highly ordered mesoporous alumina & 19.8 & 300 & $2 \min$ & $12 \mathrm{~h}$ & (Li et al. 2011) \\
\hline Calcium-doped alumina & - & 450 & - & $12 \mathrm{~h}$ & (Li et al. 2011) \\
\hline Aluminum oxide/ hydroxide nanoparticles & 0.8 & 2.0 & $300 \mathrm{~min}$ & $300 \mathrm{~min}$ & (Rathore and Mondal 2017) \\
\hline Magnetic nickel/polypyrrole (Nano) & 2.6 & 67.7 & $180 \mathrm{~min}$ & $180 \mathrm{~min}$ & (Srivastava et al. 2016) \\
\hline
\end{tabular}

لو مدينة الملأ عبدالعزيز

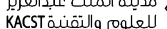


grade ferrous chloride tetra hydrate, arsenic trioxide $\left(\mathrm{As}_{2} \mathrm{O}_{3}\right)$ and sodium fluoride $(\mathrm{NaF})$ were procured from Riedel-de Haen, Peiking Chemical Works, Peiking China and SigmaAldrich, respectively. Hydrochloric acid (35\%) was taken from Pakistan Council of Scientific and Industrial Research (PCSIR) Laboratories Complex, Lahore, Pakistan while Sodium borohydride was purchased from May and Baker LTD Dagenham, England.

\section{Selection of sampling areas}

Multan City was selected as the study area. It is the fifth largest city of the country in terms of population and lies between $29^{\circ} 19^{\prime} 11^{\prime \prime}$ to $30^{\circ} 28^{\prime} 16^{\prime \prime}$ latitude. N and $70^{\circ} 58^{\prime} 34^{\prime \prime}$ to $71^{\circ} 43^{\prime} 25^{\prime \prime}$ longitude E. It is located on alluvial plain of Chenab river and falls in the Bari Doab region; area between river Chenab and river Sutlej (Murtaza et al. 2017). River Chenab serves as main source of water supply and groundwater recharge. Most of the area is fertile and productive (Greenman et al. 1967). With an area of $3,721 \mathrm{Km}^{2}$, Multan is among South Punjab main cities. The climate of the city is arid; hotter in summers and light cold in winters. The city experiences extreme weather conditions with highest and lowest temperature recorded as $54{ }^{\circ} \mathrm{C}\left(129^{\circ} \mathrm{F}\right)$ and $-1{ }^{\circ} \mathrm{C}\left(30^{\circ} \mathrm{F}\right)$, respectively. Dust storms are a common feature in the area (Randhawa et al. 2014). Annual average rainfall recorded is $320 \mathrm{~mm}$, $65 \%$ of which occurs between June and September, which adds $30 \mathrm{~mm}$ of recharge to ground water per annum (Murtaza et al. 2017).Fig. 1 shows the location map and sampling points.

Seasonal samples were collected in summer (S), winter (W) and rainy (R) seasons from all towns of City (Fig. 1), i.e., Ghanta Ghar (S1), Kumhar Mandii (S2), Mumtazabad (S3), Lari Ada (S4), Chowk Kumara (S5), Gulghushat Colony (S6), Jamila bad (S7), Lal Kurti (S8), Hamid pur

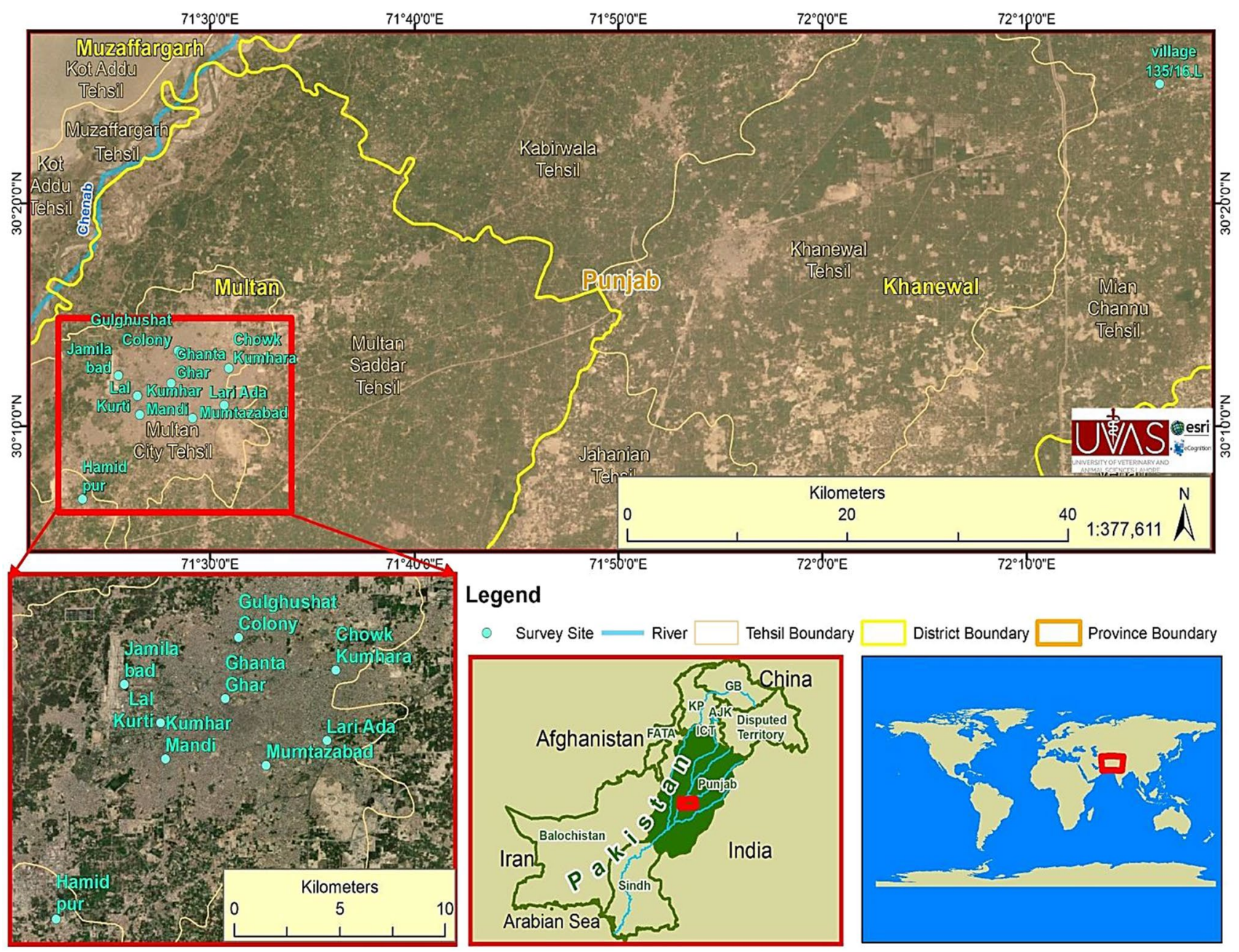

Fig. 1 Location map of study area and sampling sites 
(S9) and Peripheral area village (S10) (Supplementary data Table S1).

\section{Water sample collection}

Total thirty water samples were collected in clean and dried plastic bottles $(1.5 \mathrm{~L})$ from 10 different locations of study area. Water source in these areas is ground water. Tap water was allowed to run for $5 \mathrm{~min}$ before the collection of samples. A composite sampling technique was used to collect samples, for which 10 houses from each area were selected randomly and water was collected from taps followed by their mixing in cleaned dry plastic can. The samples were stored in ice box and transported to laboratory where they were stored in refrigerator at $4 \pm 2{ }^{\circ} \mathrm{C}$.

\section{Water analysis}

Water analysis was done to assess its quality. For arsenic detection, Arsenic kit (QuantofixArsen 10), supplied by Pakistan Council of Research in Water Resources (PCRWR), Lahore, Pakistan, was used with capability to measure total arsenic as $\mathrm{As}^{3 / 5+}$ in range of detection which is 0.01 to $0.5 \mathrm{mg} \mathrm{L}^{-1}$. Hence, the analysis data of samples is reported in form of total arsenic values (i.e., $\mathrm{As}^{3 / 5+}$ ). Considering the fact that kit is used for semi quantitative measurement, the kit was checked for accuracy with arsenic certified reference material procured from VWR. For estimation of arsenic the same protocol was used as mentioned in kit pamphlet. Fluoride content was measured by ion selective electrode (ISE-930, Spectrum, Scientific, UK) by directly immersing the electrode in water sample after performing internal calibration with Fluoride standards.

Generally, the collected samples were analyzed without any pre-treatment but for samples which showed very high concentrations of $\mathrm{F}^{-}$and $\mathrm{As}^{3 / 5+}$, dilutions were done with double distilled water before analysis while water samples with very low levels were concentrated using rotary evaporator (BuchiRotavap system) and the concentrated samples were then used for analysis and the dilution or concentration factors were adjusted in calculations.

\section{Preparation of iron doped charcoal}

Two step synthetic approach was adopted to prepare iron doped kitchen waste charcoal. In the first step, the collected kitchen waste was converted to charcoal followed by doping with iron nanoparticles in second step.

\section{Collection of kitchen waste and its pre-treatment}

Residential KW comprising majorly of rotten or expired pulses and rice, spent tea leaves, fruits and vegetable peels was collected for a period of one week. The waste was sun dried for 2-3 days and converted into fine powder using kitchen grinder.

\section{Preparation of charcoal}

The powdered material $(\sim 1 \mathrm{~kg})$ was taken in a pyrex tube which was heated in tube furnace (at PCSIR) with continuous supply of nitrogen gas $(\sim 1 \mathrm{ml} / \mathrm{min})$. The temperature was raised at the rate of $10{ }^{\circ} \mathrm{C} / \mathrm{min}$ to $600{ }^{\circ} \mathrm{C}$ and held for $3 \mathrm{~h}$ at this temperature. After that the furnace was allowed to cool while keeping nitrogen supply intact, and the resulting black powder was collected.

\section{Acid activation of charcoal}

Weighed amount (100 g) of the charcoal was stirred with $200 \mathrm{~mL}$ of 1:1 $\mathrm{HCl}$ : distilled water for $2 \mathrm{~h}$ at room temperature, filtered, followed by 3-4 times washing with distilled water, air drying and oven drying at $60{ }^{\circ} \mathrm{C}$ for $1-2 \mathrm{~h}$. The activated charcoal was stored in air-tight container till further use.

\section{Iron nanoparticles doped charcoal (Fe-KWC)}

The experimental setup included a two-necked round bottom flask fitted with dropping funnel at one neck while the other one was attached to nitrogen gas supply line. To the flask containing suspension of charcoal $(40.0 \mathrm{~g})$ and iron (II) chloride tetra hydrated $(10.0 \mathrm{~g})$ in $500 \mathrm{~mL}$ of double distilled water; sodium borohydride solution in deoxygenated water $(0.9 \mathrm{~g} / 250 \mathrm{~mL})$ was added drop wise with vigorous stirring at room temperature to ensure reduction of $\mathrm{Fe}$ (II) to $\mathrm{Fe}(0)$. Following complete addition of sodium borohydride, the suspension was filtered and residue containing charcoal doped with Fe nanoparticles was dried in vacuum oven for $3 \mathrm{~h}$ at $70{ }^{\circ} \mathrm{C}$. Oven dried charcoal was stored in air-tight reagent bottle to prevent its deactivation.

\section{Characterization of biomass}

Prepared nano-adsorbent, i.e., Fe-KWC was characterized using different techniques. FTIR analysis was carried out using Tensor-27 FTIR Spectrometer by using ATR. SEM analysis was done by Variable pressure scanning electron microscope (model Tescan Vega3 LMU, Czech Repulic) while XRD was conducted on Philips/PANalytical X'Pert Powder XRD in the scan range of $5.0000-120.0000^{\circ}$ using continuous mode and step size of $0.0250^{\circ}$. 


\section{Adsorption studies}

For adsorption studies, $\mathrm{As}^{3+}$ stock solution $(1000 \mathrm{mg}$ $\mathrm{L}^{-1} ; 0.133 \mathrm{~g}$ of arsenic trioxide $/ 100 \mathrm{~mL}$ of diluted $\mathrm{HCl})$ and Fluoride stock solution $\left(1000 \mathrm{mg} \mathrm{L}^{-1} ; 0.221 \mathrm{~g}\right.$ $\mathrm{NaF} / 100 \mathrm{~mL}$ distilled water) were used for preparing working solutions.

Batch adsorption studies were performed to evaluate the efficacy of $\mathrm{Fe}-\mathrm{KWC}$ for removal of $\mathrm{As}^{3+}$ and $\mathrm{F}^{-}$separately in simulated setting as well as in combined settings in real water samples. The studies were performed in triplicate and data is presented as average of these. For this purpose, $50 \mathrm{~mL}$ of $\mathrm{As}^{3+}$ and $\mathrm{F}^{-}$working solutions (25-200 $\mathrm{mg} \mathrm{L}^{-1}$ ), after $\mathrm{pH}$ adjustment (1-12) with $0.1 \mathrm{M}$ of $\mathrm{HCl}$ or $\mathrm{NaOH}$, were allowed to remain in contact for different time periods $(2-120 \mathrm{~min})$ and at varying temperature $\left(20-100{ }^{\circ} \mathrm{C}\right)$ with adsorbent dose of $0.01-0.11 \mathrm{~g}$. After that, the contents were Cannula filtered to remove the adsorbent and resulting filtrate was analyzed for respective contaminant concentration. The contact time, temperature, initial $\mathrm{pH}$, initial ion concentration and adsorbent dose were optimized by varying one parameter at a time. The initial concentration in each case, i.e., $\mathrm{As}^{3+}$ and $\mathrm{F}^{-}$was chosen to assess the maximum adsorption capacity of the prepared adsorbent. The essence of selection of this high concentration than the normal prevailing value of the contaminants in water is because it helps in determining the maximum potential of the adsorbent to uptake these contaminants thereby allowing it to be used for either multiple times or longer periods of the time till its full adsorption capacity is attained. The adsorption percentage and adsorption capacity are calculated using Eq. 1 and 2 as presented in Table 2.

The data obtained were used to predict the adsorbent's behavior by applying various models, i.e., kinetic, adsorption and diffusion models. In addition, thermodynamic studies were also carried out to check the efficacy of adsorption process. The models applied for assessment were in accordance with similar studies conducted for determination of effectiveness of synthesized adsorbents (Darwish et al. 2019; de Jesús Ruíz-Baltazar et al. 2019). The models applied and their related equations are also given in Table 2.

\section{Treatment of contaminated water samples with iron doped charcoal}

$50 \mathrm{~mL}$ of drinking water sample (composite sample) was taken in a conical flask. After adjustment of $\mathrm{pH}$ to $3,0.1 \mathrm{~g}$ of nano-adsorbent was added. The contents were stirred at $40^{\circ} \mathrm{C}$ for $30 \mathrm{~min}$ for $\mathrm{As}^{3+}$ and $\mathrm{F}^{1-}$. After this the treated samples were Cannula filtered and analyzed for $\mathrm{As}^{3+}$ and $\mathrm{F}^{-}$concentration using arsenic kit and Fluoride ISE, respectively.

\section{Results and discussion}

The water samples collected from 10 different areas in three seasons were analyzed for total arsenic content $\left(\mathrm{As}^{3 / 5+}\right)$ and $\mathrm{F}^{-}$levels followed by treatment with prepared nano-adsorbent (Fe-KWC).

\section{Water analysis}

The results of water analysis, along with sample code (ID), Depth (D), coordinates and analyzed parameters are summarized in supplementary material (Table 1S). Table 3 provides concentration of $\mathrm{As}^{3 / 5+}$ and $\mathrm{F}^{-}$in samples during three seasons.

\section{Fe-KWC preparation and characterization}

Keeping in view the perspective of waste management, Fe-KWC preparation was done by employing kitchen waste charcoal (KWC) as support material onto which the $\mathrm{Fe}$ nanoparticles were doped using sodium borohydride as reducing agent. The chemical reaction resulted is as follows:

$2 \mathrm{FeCl}_{3}+6 \mathrm{NaBH}_{4}+18 \mathrm{H}_{2} \mathrm{O} \rightarrow 2 \mathrm{Fe}^{0}+21 \mathrm{H}_{2}+6 \mathrm{~B}(\mathrm{OH})_{3}+6 \mathrm{NaCl}$

Material hence obtained was characterized using different techniques to verify the formation of Fe-KWC.

\section{FTIR}

The FTIR spectra of Fe-KWC (Fig. 2a) showed all the peaks typical of the charcoals. Peaks appearing in range of $3800-2800 \mathrm{~cm}^{-1}$ are due to the presence of aliphatic and aromatic carbon containing multiple molecular components including cellulose, lignin and other organic compounds. The carboxylic groups $(\mathrm{C}=\mathrm{O})$ present in the charcoal are indicated by appearance of peak at $1620.92 \mathrm{~cm}^{-1}$. The peaks appearing at 1384.50 and $1117.60 \mathrm{~cm}^{-1}$ are due to esteric group presence (Butt et al. 2014; Hammud et al. 2016).

\section{SEM}

The SEM image of the Fe-KWC is presented in Fig. 3. The image shows white small particles of iron which are embedded on the big lumps of charcoal and homogeneously distributed. Similar studies carried out for synthesis of nanoparticles doped charcoal showed the similar results and doping pattern (Rodríguez-Pérez et al. 2011).

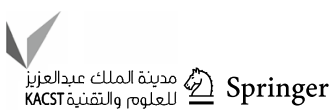


Table 2 Different theoretical model equations used for adsorption studies

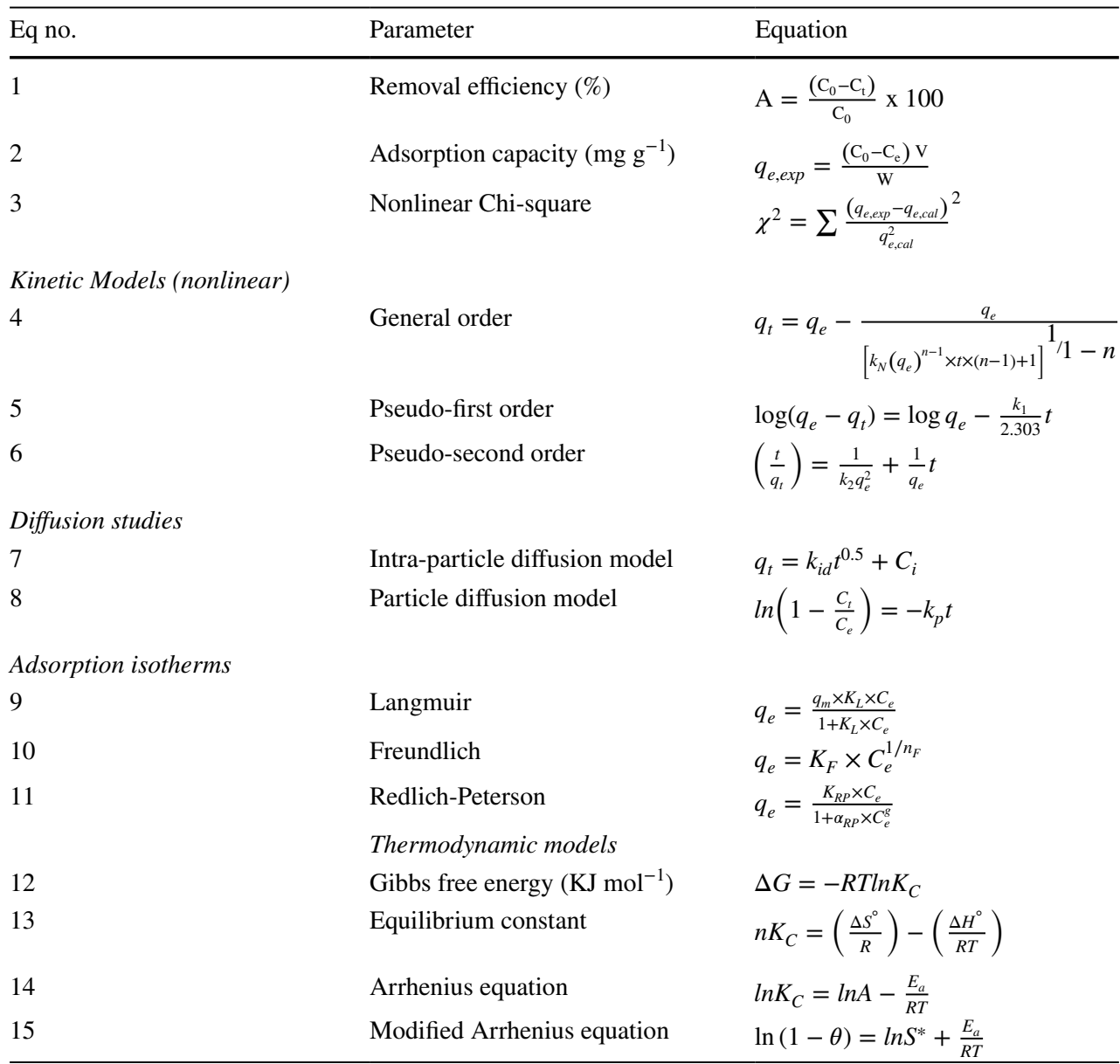

$C_{0}\left(\mathrm{mg} \mathrm{L}^{-1}\right)$, Initial adsorbate concentration; $C_{t}\left(\mathrm{mg} \mathrm{L}^{-1}\right)$, Adsorbate concentrations at time $t ; C_{e}\left(\mathrm{mg} \mathrm{L}^{-1}\right)$, Adsorbate concentrations at equilibrium; $V(\mathrm{~L})$, Volume of the solution; $W(\mathrm{~g})$, Weight of the adsorbent used; $q_{e, \exp }\left(\mathrm{mg} \mathrm{g}^{-1}\right)$, Experimental equilibrium capacity; $q_{e, \text { cal }}\left(\mathrm{mg} \mathrm{g}^{-1}\right)$, Theoretical equilibrium capacity; $q_{e}\left(\mathrm{mg} \mathrm{g}^{-1}\right)$, Amount of adsorbent at equilibrium; $q_{t}\left(\mathrm{mg} \mathrm{g}^{-1}\right)$, Amount of adsorbent at time $t(\min ) ; k_{N}$ $\left(\mathrm{min}^{-1}\left(\mathrm{~g} \mathrm{mg}^{-1}\right)^{\mathrm{n}-1}\right)$, Rate constants for general order; $k_{1}\left(\mathrm{~min}^{-1}\right)$, Rate constants for pseudo-first order; $k_{2}$ $\left(\mathrm{g} \mathrm{mg}^{-1} \mathrm{~min}^{-1}\right)$, Rate constant for pseudo-second order; $k_{i d}\left(\mathrm{mg} \mathrm{g}^{-1} \mathrm{~min}^{-0.5}\right)$, Rate parameter of stage I; $C_{i}$, Thickness of boundary layer; $q_{m}\left(\mathrm{mg} \mathrm{g}^{-1}\right)$ is the maximum adsorption capacity. $K_{\mathrm{L}}\left(\mathrm{L} \mathrm{mg}^{-1}\right)$ and $\mathrm{KF}(\mathrm{mg}$ $\left.\mathrm{g}^{-1}\left(\mathrm{mg} \mathrm{L}^{1-}\right)^{-1 / \mathrm{nF}}\right)$ are Langmuir and Freundlich constants related to rate of adsorption; $\mathrm{nF}$ is the Freundlich dimensionless exponent. $K_{\mathrm{RP}}\left(\mathrm{L} \mathrm{g}^{-1}\right)$ and $\mathrm{a}_{\mathrm{RP}}\left(\mathrm{mg} \mathrm{L}^{-1}\right)^{-\mathrm{g}}$ are R-P constants while $\mathrm{g}$ is R-P exponent $(0<g \leq 1) . K_{C}$ is equilibrium constant $=C_{s} / C_{e}$ where $C_{s}\left(\mathrm{mg} \mathrm{L}^{-1}\right)$ is equilibrium concentration of adsorbent, $C_{e}\left(\mathrm{mg} \mathrm{L}^{-1}\right)$ equilibrium concentration in solution, $R\left(\mathrm{~J} \mathrm{~mol}^{-1} \mathrm{~K}^{-1}\right)$ is ideal gas constant and $T(\mathrm{~K})$ is temperature; $E_{a}=$ activation energy; $\mathrm{A}=$ frequency factor; $\mathrm{S}^{*}=$ Sticking probability, $\theta=$ surface coverage and is equal to $\left[1-\left(\mathrm{C}_{\mathrm{e}} / \mathrm{C}_{\mathrm{t}}\right)\right]$

\section{Powder XRD}

Iron-doped Powder XRD spectra of the charcoal is presented in Fig. 4. The overall amorphous nature of sample prepared is indicated with appearance of few broadened peaks at $2 \theta$ values of $20.9^{\circ}, 26.7^{\circ}, 36.6^{\circ}, 42.4^{\circ}, 50.2^{\circ}$, $60.1^{\circ}, 67.8^{\circ}$ and $75.5^{\circ}$. The peak appearing at $26.7^{\circ}$ is typical of activated carbon as reported by previous studies (Xie et al. 2014) and showed matching with Quartz JCDP 98-008-3849 as shown in Fig. 4 (vertical spark lines).

Previous studies have also reported the presence of silicates in the biochar (Qian et al. 2017). The doping with iron
Table 3 Seasonal concentration of $\mathrm{As}^{3 / 5+}$ and $\mathrm{F}^{-}$in water samples

\begin{tabular}{llrrr}
\hline Sample ID & Min & Max & Avg & \multicolumn{1}{l}{ SD } \\
\hline Arsenic $\left(\mathrm{mg} \mathrm{L}^{-1}\right)$ & & & & \\
Summer & BDL & 0.20 & 0.05 & 0.06 \\
Rainy & BDL & 0.10 & 0.03 & 0.04 \\
Winter & BDL & 0.12 & 0.02 & 0.04 \\
Fluoride $\left(\mathrm{mg} \mathrm{L}^{-1}\right)$ & & & & \\
Summer & BDL & 409.10 & 57.61 & 125.24 \\
Rainy & 1.20 & 227.90 & 28.21 & 70.29 \\
Winter & 2.70 & 4.50 & 3.27 & 0.50 \\
\hline
\end{tabular}

*Below detection limits: Detection limits; As $=0.005 \mathrm{mg} \mathrm{L}^{-1} ; \mathrm{F}^{1}=0$ (ion concentration range 0.01-19,999 $\mathrm{mg} \mathrm{L}^{-1}$ ) 


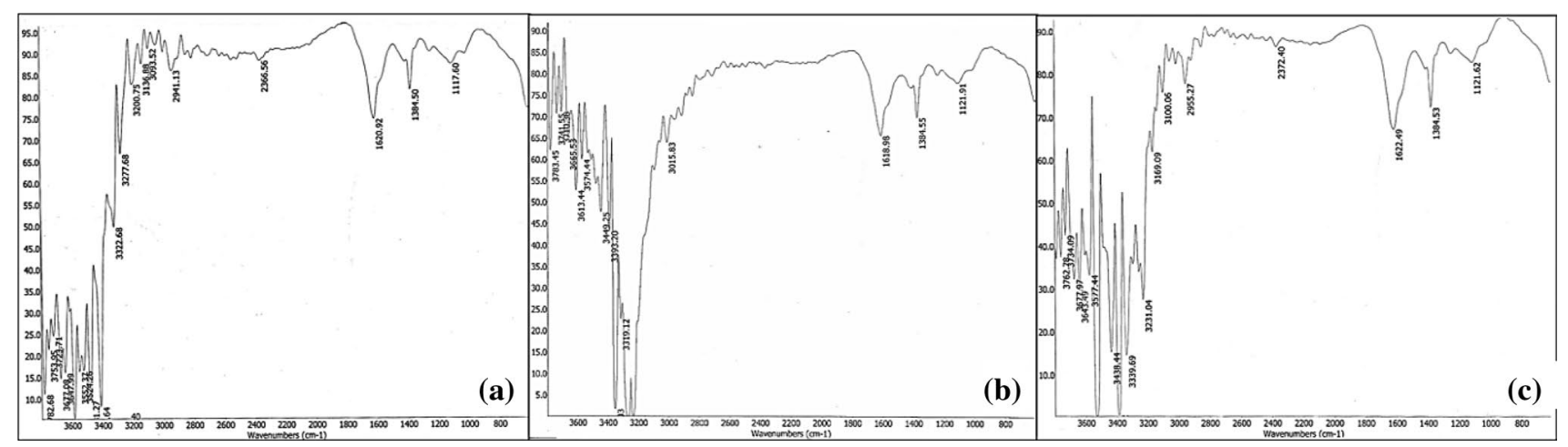

Fig. 2 FTIR spectra of virgin Fe-KWC (a) and Spent Fe-KWC after adsorption of Arsenic (b) and Fluoride (c)

(a)

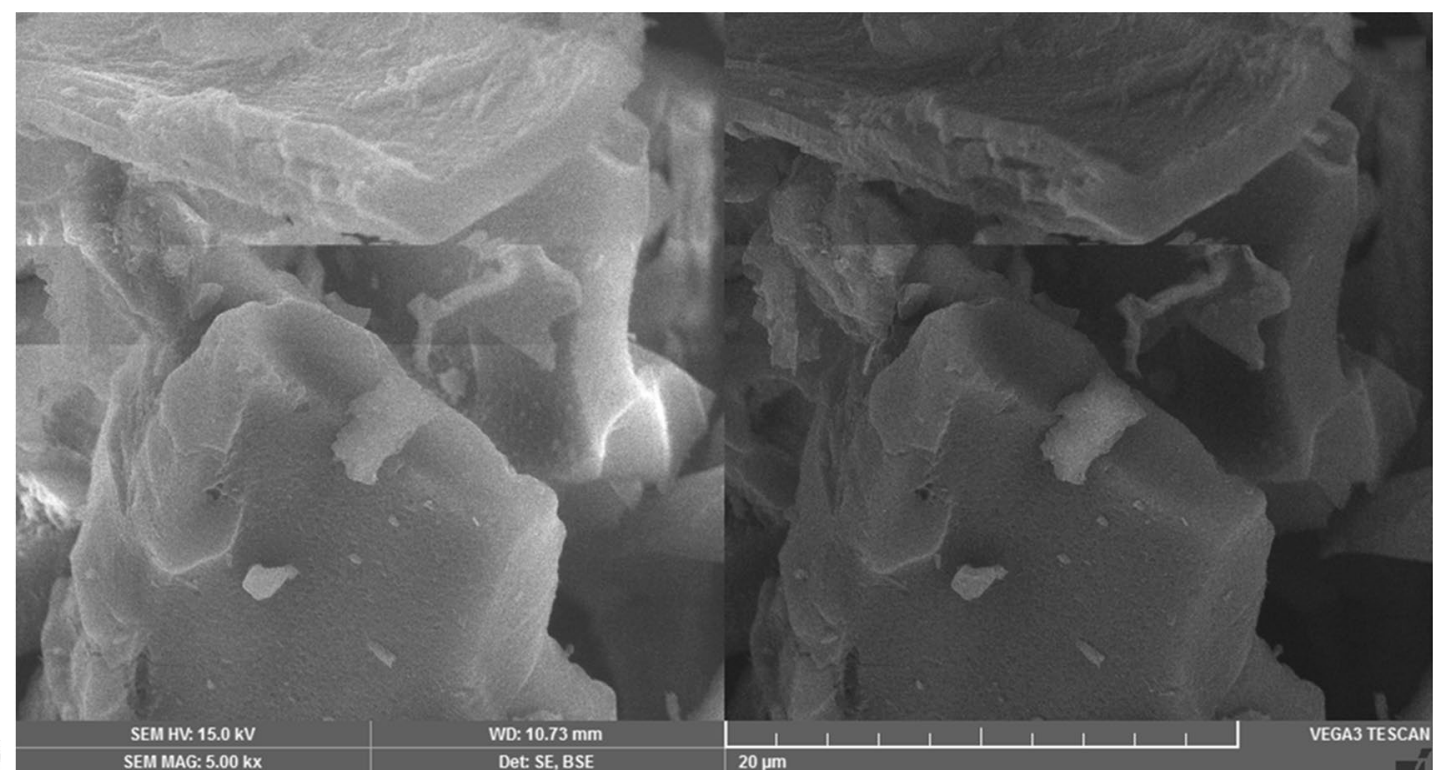

(b)

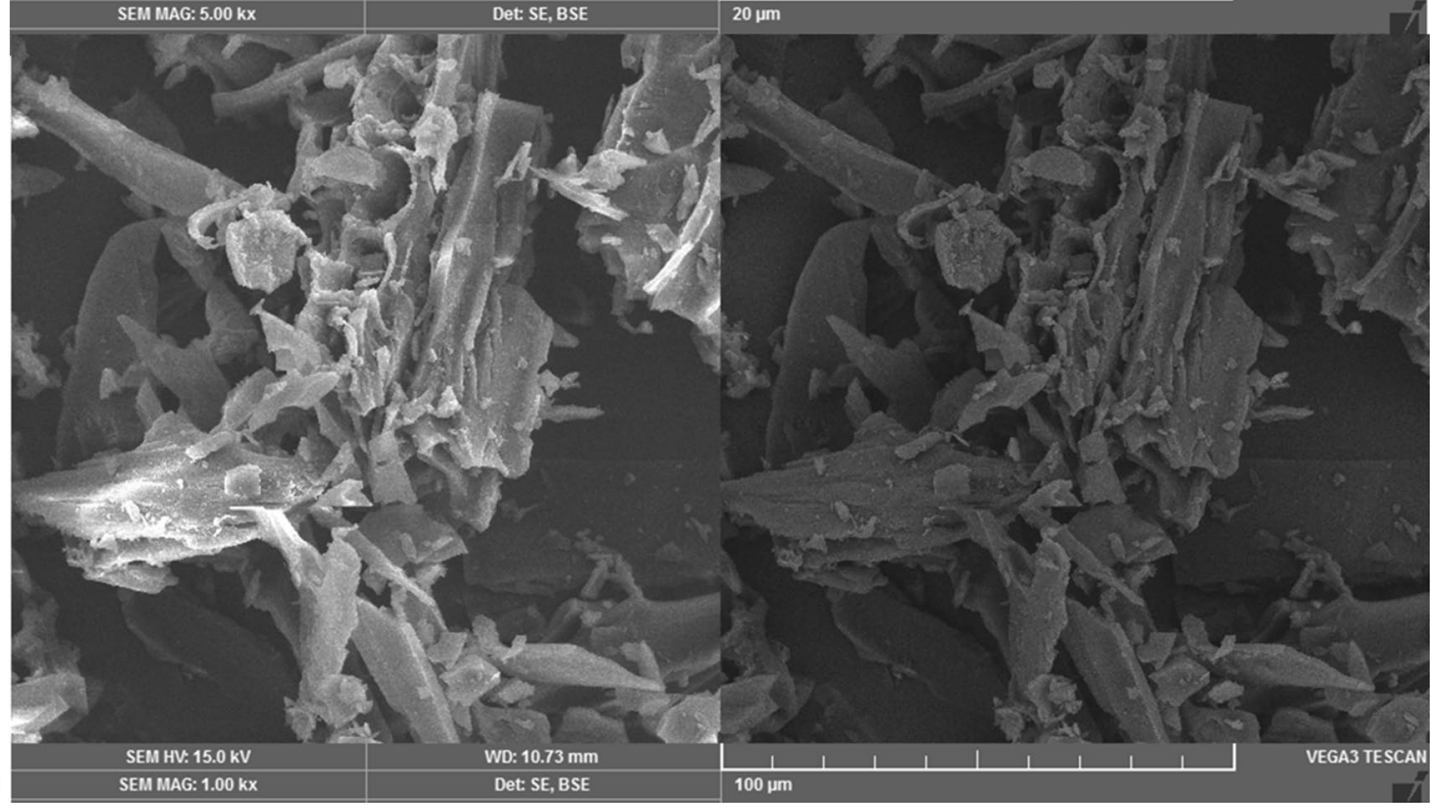

Fig. 3 SEM image of Fe-KWC showing smooth doping of iron nanoparticles on to KWC porous structure at resolutions of a $10 \mu \mathrm{m}$ and $\mathbf{b}$ $100 \mu \mathrm{m}$ 


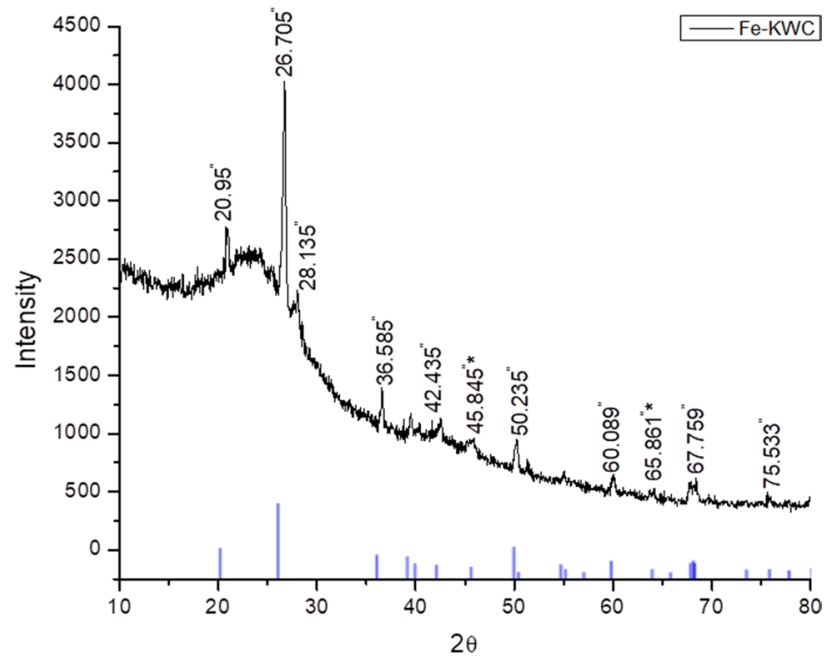

Fig. 4 Fe-KWC powder XRD spectra, showing matching with Quartz JCDP 98-008-3849 (blue spark lines and ") and zero-valent iron (*)

NPs results in appearance of small peaks at $45.8^{\circ}$ and $65.8^{\circ}$ matching well with the zero-valent iron body centered cubic structure denoting hkl values of 110 and 200 (Singhal et al. 2012; Shi et al. 2011; Sun et al. 2006) which are different from the ones shown by iron oxides (Sun et al. 2006). The smaller size of nanoparticles prepared is also indicated by boarding of peaks and amorphous nature of spectra.

\section{Adsorption studies}

\section{Effect of contact time, adsorption kinetics and diffusion models}

Adsorption of both $\mathrm{F}^{-}$and $\mathrm{As}^{3+}$ as a function of contact time were carried out at room temperature; the results of which are presented in Fig. 5 for time span of 120 min. Adsorption equilibrium was achieved in $15 \mathrm{~min}$ for the $\mathrm{F}^{-}$, while for $\mathrm{As}^{3+}$ it was attained in $20 \mathrm{~min}$.

The data obtained were fitted to kinetic models (general, pseudo-first and pseudo-second orders) in their nonlinear form, respectively. The pseudo-first order model holds good for high concentration of adsorbates while the pseudo-second order model fits well to low concentrations (Azizian 2004). When adsorption is based on diffusion via interface, the kinetics is best explained by the pseudo-first order while when chemisorption takes place pseudo-second order model defines the process (Sahoo and Prelot 2020). In cases where the change can occur from one rate order to another over the course of adsorption; in such cases general order model best describes the adsorption process (Lima et al. 2015). The results of model application are presented in Fig. 5, while the associated parameters determined in each case are given in Table 4. The best-fitting model as judged on basis of high $\mathrm{R}^{2}$ value, smaller $\mathrm{SD}$ and reduced $-\chi^{2}$ value which clearly shows that general order model holds good in case $\mathrm{As}^{3+}$ and pseudo-first order fits well in case of $\mathrm{F}^{-}$when compared with rest of the models. In the previously reported
Fig. 5 Fitting of kinetic models to Fe-KWC for adsorption of Fluoride (a) and Arsenic (b)
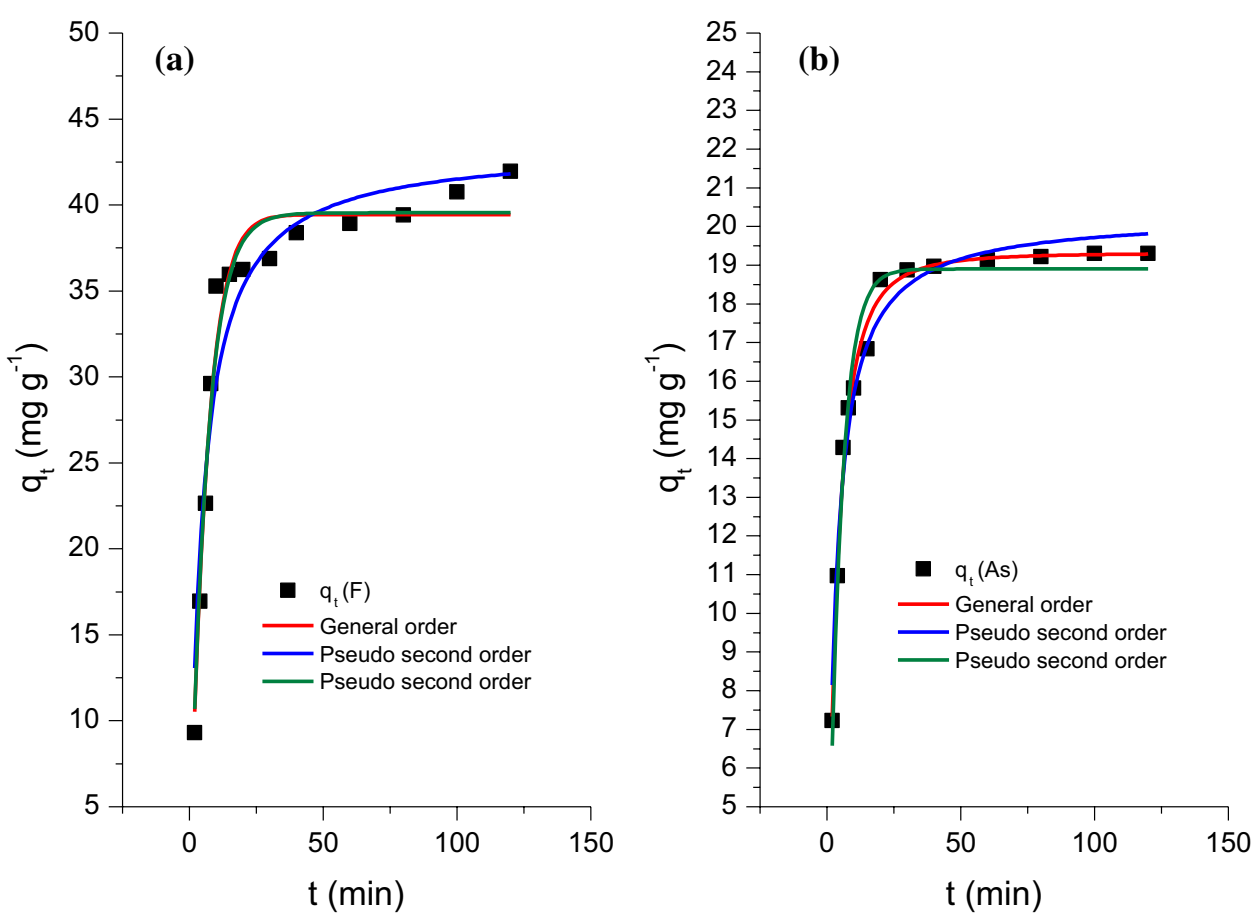
Table 4 Adsorption kinetics and goodness to fit parameters for $\mathrm{F}^{-}$ and $\mathrm{As}^{3+}$ adsorption on nano-adsorbent

\begin{tabular}{|c|c|c|c|}
\hline Model & Parameter & Value $(\mathrm{F})$ & Value (As) \\
\hline \multirow[t]{6}{*}{ General order } & $q_{e} \exp \left(\mathrm{mg} \mathrm{g}^{-1}\right)$ & 35.95 & 18.62 \\
\hline & $k\left(\min ^{-1}\right)$ & 0.188 & 0.081 \\
\hline & $q_{e},{ }_{\mathrm{cal}}\left(\mathrm{mg} \mathrm{g}^{-1}\right)$ & 39.44 & 19.31 \\
\hline & $R_{a d j}^{2}$ & 0.9611 & 0.9906 \\
\hline & $S D$ & 1.92 & 0.364 \\
\hline & Reduced- $\chi^{2}$ & 3.96 & 0.133 \\
\hline \multirow[t]{6}{*}{ Pseudo-first order } & $q_{e}$ exp $\left(\mathrm{mg} \mathrm{g}^{-1}\right)$ & 35.95 & 18.62 \\
\hline & $k_{l}\left(\min ^{-1}\right)$ & 0.158 & 0.214 \\
\hline & $q_{e}{ }^{\prime} \mathrm{cal}\left(\mathrm{mg} \mathrm{g}^{-1}\right)$ & 39.54 & 18.90 \\
\hline & $R_{a d j}^{2}$ & 0.9639 & 0.9758 \\
\hline & $S D$ & 1.915 & 0.585 \\
\hline & Reduced $\chi^{2}$ & 3.67 & 0.342 \\
\hline \multirow[t]{6}{*}{ Pseudo-second order } & $q_{e}, \exp \left(\mathrm{mg} \mathrm{g}^{-1}\right)$ & 35.95 & 18.62 \\
\hline & $k_{2}\left(\min ^{-1}\right)$ & 0.005 & 0.016 \\
\hline & $q_{e},_{\mathrm{cal}}\left(\mathrm{mg} \mathrm{g}^{-1}\right)$ & 43.42 & 20.304 \\
\hline & $R_{a d j}^{2}$ & 0.9299 & 0.9756 \\
\hline & $S D$ & 2.66 & 0.587 \\
\hline & Reduced- $\chi^{2}$ & 7.120 & 0.342 \\
\hline \multirow[t]{6}{*}{ Particle diffusion } & $k_{p I}\left(\mathrm{mg} \mathrm{g}^{-1} \min ^{-1}\right)$ & -2.076 & -1.407 \\
\hline & $R_{l}^{2}$ & 0.9263 & 0.8685 \\
\hline & $k_{p 2}\left(\mathrm{mg} \mathrm{g}^{-1} \min ^{-1}\right)$ & -0.572 & -0.621 \\
\hline & $R_{2}^{2}$ & 0.9575 & 0.9825 \\
\hline & $k_{p 3}\left(\mathrm{mg} \mathrm{g}^{-1} \min ^{-1}\right)$ & - & -0.292 \\
\hline & $R_{3}^{2}$ & & 0.8241 \\
\hline \multirow[t]{9}{*}{ Intra-particle diffusion } & $k_{i d l}\left(\mathrm{mg} \mathrm{g}^{-1} \min ^{-0.5}\right)$ & 14.807 & 5.93 \\
\hline & $C i_{1}\left(\mathrm{mg} \mathrm{g}^{-1}\right)$ & -12.351 & -0.95 \\
\hline & $R_{l}^{2}$ & 0.9907 & 0.9693 \\
\hline & $k_{i d 2}\left(\mathrm{mg} \mathrm{g}^{-1} \min ^{-0.5}\right)$ & 0.832 & 1.239 \\
\hline & $C i_{2}\left(\mathrm{mg} \mathrm{g}^{-1}\right)$ & 32.637 & 11.893 \\
\hline & $R_{2}^{2}$ & 0.9533 & 0.9923 \\
\hline & $k_{i d 3}\left(\mathrm{mg} \mathrm{g}^{-1} \min ^{-0.5}\right)$ & 0.965 & 0.129 \\
\hline & $C i_{3}\left(\mathrm{mg} \mathrm{g}^{-1}\right)$ & 31.179 & 17.965 \\
\hline & $R_{3}^{2}$ & 0.9266 & 0.9603 \\
\hline
\end{tabular}

studies, adsorption of both $\mathrm{F}^{-}$and $\mathrm{As}^{5+}$ onto goethite was best explained by pseudo-second order (Tang et al. 2010).

Particle and intra-particle diffusion models are also applied to the experimental data to get insight into adsorption retention process that if it is governed by particle or pore diffusion which is determined from the higher $R^{2}$ value to the models applied. The intra-particle diffusion model (Weber and Morris plot) applied to full range studied and showed nonlinear dependence fitting into three steps (Fig. 6) in both the cases, i.e., fluoride and arsenic indicating that adsorption is controlled by multiple phenomena starting with quick initial adsorption followed by slow adsorption rate near equilibrium and almost plateau behavior due to transportation of adsorbate into the adsorbent pores. The intra-particle diffusion model fits well considering the $R^{2}$ value as compared to the diffusion model (i.e., Chanda model) for $\mathrm{F}^{-}$and $\mathrm{As}^{3+}$. The porous structure of the nano-adsorbent based on charcoal is well in line with the model fitting results.

\section{Effect of temperature and thermodynamic studies}

For determination of the effect of temperature on the adsorption capacity of the prepared nano-adsorbent (FeKWC); experiments were performed at varying temperature from 40 to $100{ }^{\circ} \mathrm{C}$ (Fig. 7a). Figure 7a showed that as the temperature increase, adsorption of both $\mathrm{As}^{3+}$ and $\mathrm{F}^{-}$increase slightly pointing to endothermic nature of the process. There is small increase in $q_{e}$ value, i.e., 20.0 to $20.9 \mathrm{mg} \mathrm{g}^{-1}$ for $\mathrm{As}^{3+}$ and 38.8 to $42.2 \mathrm{mg} \mathrm{g}^{-1}$ for $\mathrm{F}^{-}$; hence, all the further studies were performed at room temperature.

The data were subjected to thermodynamic models (Fig. $7 \mathrm{~b}, \mathrm{c}$ ) to calculate $\Delta \mathrm{H}^{\circ}, \Delta \mathrm{S}^{\circ}, \Delta \mathrm{G}^{\circ}$ and Ea from fitting parameters. The values of these, tabulated in Table 5 , revealed about the adsorption process being spontaneous $\left(-\Delta \mathrm{G}^{\circ}\right)$ and endothermic $\left(-\Delta \mathrm{H}^{\circ}\right)$. The positive value of $\left(+\Delta \mathrm{S}^{\circ}\right)$ also denotes randomness in the system because of solid-liquid interaction (Batool et al. 2018).

\section{Effect of $\mathrm{pH}$ and adsorbent dose}

The effect of initial $\mathrm{pH}$ on the adsorption capacity of FeKWC was also studied, and it was observed that at acidic $\mathrm{pH}$ value both arsenic and fluoride showed good appreciable adsorption on the surface of Fe-KWC (Fig. 8). At pH 3 Fe-KWC showed $20.4 \mathrm{mg} \mathrm{g}^{-1}$ and $59.3 \mathrm{mg} \mathrm{g}^{-1}$ adsorption capacity for arsenic and fluoride, respectively. Above that the adsorption decrease with increase in $\mathrm{pH}$ value; hence, further studies were performed at $\mathrm{pH} 3$.

Adsorbent dose has also shown high impact on the adsorption; generally with increase in adsorbent dose adsorption capacity decrease till it attains equilibrium. In both the cases the equilibrium is attained by using $0.06 \mathrm{~g}$ adsorbent, and hence, the same dose was used for performing further studies (Fig. 8). Earlier studies have also pointed to the fact that at acidic $\mathrm{pH}$ values the adsorption of both $\mathrm{F}^{-}$and $\mathrm{As}^{5+}$ is higher and decrease with increase in $\mathrm{pH}$ owing to the decrease in protonated surface sites (Tang et al. 2010; Li et al. 2011). On contrary in the case of aluminum oxide/hydroxide nanoparticles, the maximum adsorption of $\mathrm{F}^{-}$occurred at $\mathrm{pH} 7$ while that of $\mathrm{As}^{3+}$ occurs in same $\mathrm{pH}$ as reported in present studies, i.e., 4 (Rathore and Mondal 2017). 

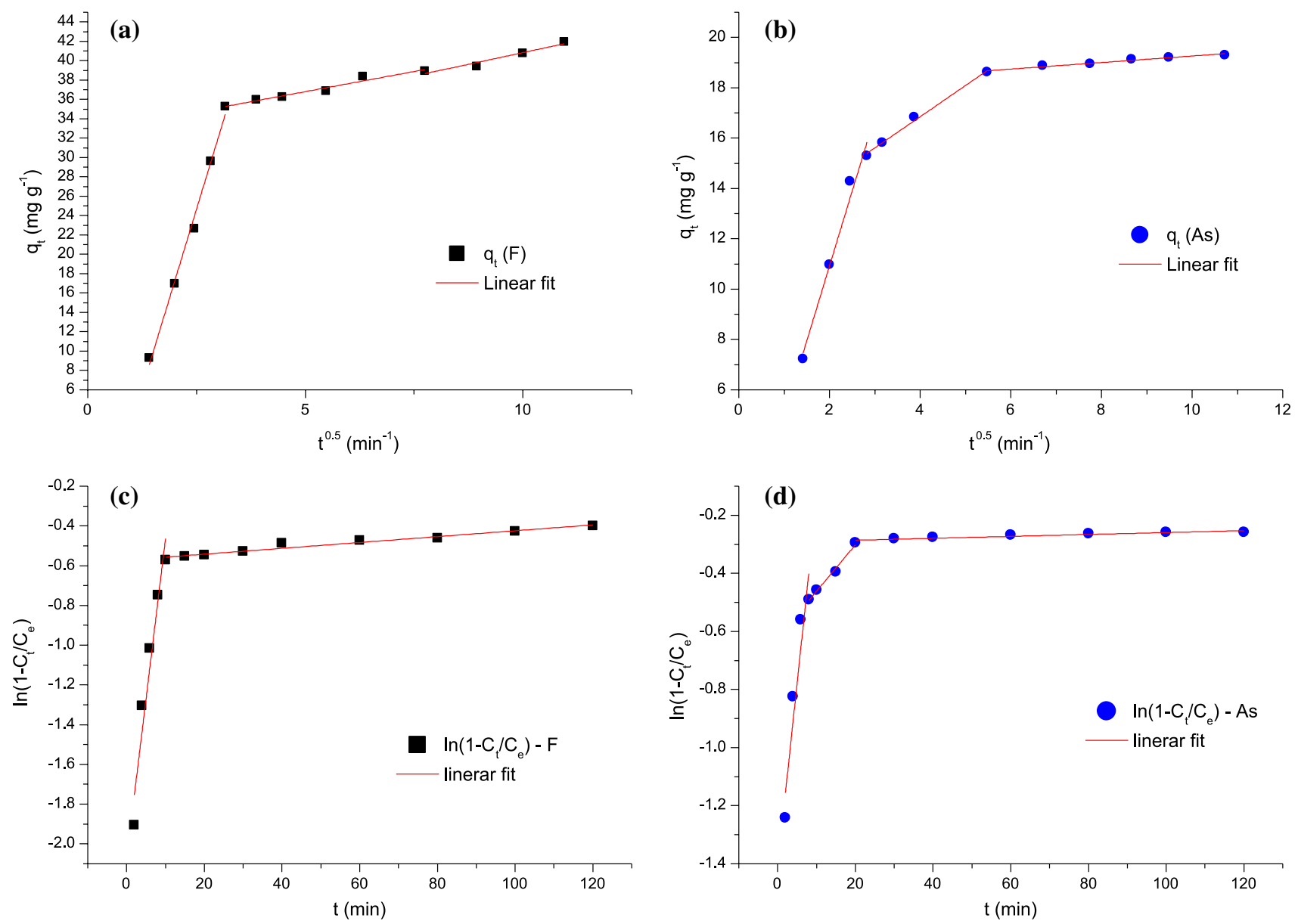

Fig. 6 Plot showing implication of diffusion models, i.e., Weber and Moris plot to fluoride (a) and arsenic (b) and Chanda plots to fluoride (c) and arsenic (d)

\section{Effect of adsorbate initial concentration and adsorption isotherms}

For determination of optimal amount of adsorbate that can be removed effectively, adsorption capacity was checked by employing various concentrations of arsenic (50-250 $\mathrm{mg} \mathrm{L}^{-1}$ ) and fluoride (100-400 $\mathrm{mg} \mathrm{L}^{-1}$ ) at room temperature and $\mathrm{pH} 3$ with $0.06 \mathrm{~g}$ nano-adsorbent. In both cases incremental increase in $q t\left(\mathrm{mg} \mathrm{g}^{-1}\right)$ with escalating concentration was observed till it achieves the equilibrium (Fig. 9). The application of three adsorption isotherms (Langmuir, Freundlich and R-P) on experimental points were done, and it was clear from fitting parameters (Table 6) that the best-fit model for $\mathrm{F}^{-}$is R-P and for $\mathrm{As}^{3+}$ it is Freundlich. The best-fit model was decided on basis of highest $\mathrm{R} 2$, lowest reduced $\chi^{2}$ and smallest SD value. The $\mathrm{q}_{\mathrm{m}}$ as obtained from the fitting comes out to be 342.8 and $159.5 \mathrm{mg} \mathrm{g}^{-1}$, respectively, for $\mathrm{F}^{-}$and $\mathrm{As}^{3+}$ in just 15-20 min.

As demonstrated by Rathore et al. (2017), adsorption of $\mathrm{As}^{3+}$ and $\mathrm{F}^{-}$on aluminum oxide/hydroxide nanoparticles obeyed Langmuir adsorption model with maximum adsorption capacity of $833.33 \mu \mathrm{g} \mathrm{g}^{-1}$ and $2000 \mu \mathrm{g} \mathrm{g}^{-1}$ for $\mathrm{As}^{3+}$ and $\mathrm{F}^{-}$, respectively, at optimized conditions. For the studies conducted to investigate the potential of Nickel/polypyrrole (Ni/PPy) nanocomposites toward $\mathrm{As}^{3+}$ and $\mathrm{F}^{-}$removal from polluted water showed much lower adsorption capacities for $\mathrm{As}^{3+}$ and $\mathrm{F}^{-}$, i.e., 2.64 and $67.71 \mathrm{mg} \mathrm{g}^{-1}$, respectively, as obtained from Langmuir adsorption model fitting (Srivastava et al. 2016). 

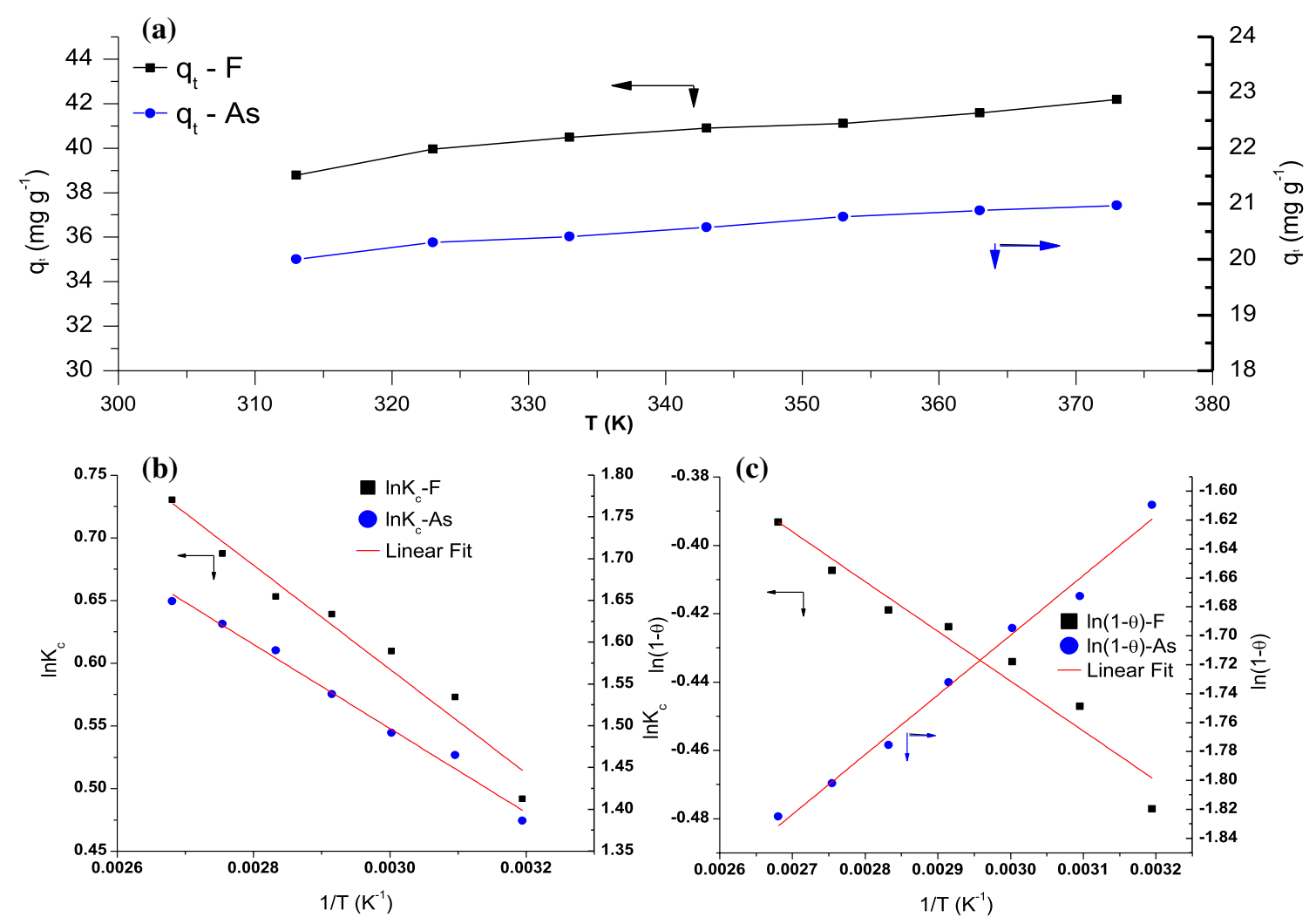

Fig. 7 Plots showing a effect of temperature on adsorption capacity of Fe-KWC b plot of $\ln K_{C} \mathrm{vs} T^{-1}$ and $\mathbf{c}$ plot of $\ln (1-\theta)$ versus $T^{-1}$ for Fluoride (black-shaded square) and arsenic (blue-shaded circle)

Table 5 Activation and thermodynamic parameters' values for adsorption of $\mathrm{F}^{-}$and $\mathrm{As}^{3+}$ onto Fe-KWC nanoadsorbent

\begin{tabular}{cllllll}
\hline$T(\mathrm{~K})$ & $K_{C}$ & $\Delta G^{o} \mathrm{~kJ} \mathrm{~mol}^{-1}$ & $\Delta H^{o} \mathrm{~kJ} \mathrm{~mol}^{-1}$ & $\Delta S^{o} \mathrm{~kJ} \mathrm{~mol}^{-1}$ & $E_{a} \mathrm{~kJ} \mathrm{~mol}^{-1}$ & $\mathrm{~S}^{*} \mathrm{~kJ} \mathrm{~mol}^{-1}$ \\
\hline Fluoride & & & & & \\
313 & 1.635 & -1.279 & & & \\
323 & 1.773 & -1.538 & & & \\
333 & 1.894 & -1.687 & & & \\
343 & 1.922 & -1.821 & -3.608 & 0.016 & -0.20 \\
353 & 1.988 & -1.917 & & & \\
363 & 2.076 & -2.074 & & & \\
373 & 0.477 & -2.264 & & & \\
Arsenic & & & & & \\
313 & 1.386 & -3.608 & & & \\
323 & 1.465 & -3.933 & & & \\
333 & 1.492 & -4.130 & & & \\
343 & 1.538 & -4.385 & -4.419 & 0.0257 & \\
353 & 1.590 & -4.666 & & & \\
363 & 1.622 & -4.894 & & & \\
373 & 1.649 & -5.114 & & & \\
\hline
\end{tabular}

$1633.21 \mathrm{~cm}^{-1}$ owing to attach bonding of As and $\mathrm{F}^{1-}$. Similarly, the peak shifting of esteric group is observed from 1383.58 to $1383.21 \mathrm{~cm}^{-1}$ along with reduction in intensity of the peak at $1112.79 \mathrm{~cm}^{-1}$ (Yu et al. 2010).
The FTIR spectra of spent Fe-KWC is given in Fig. 2b, c which shows the shifting of peak from 1631.49 to 

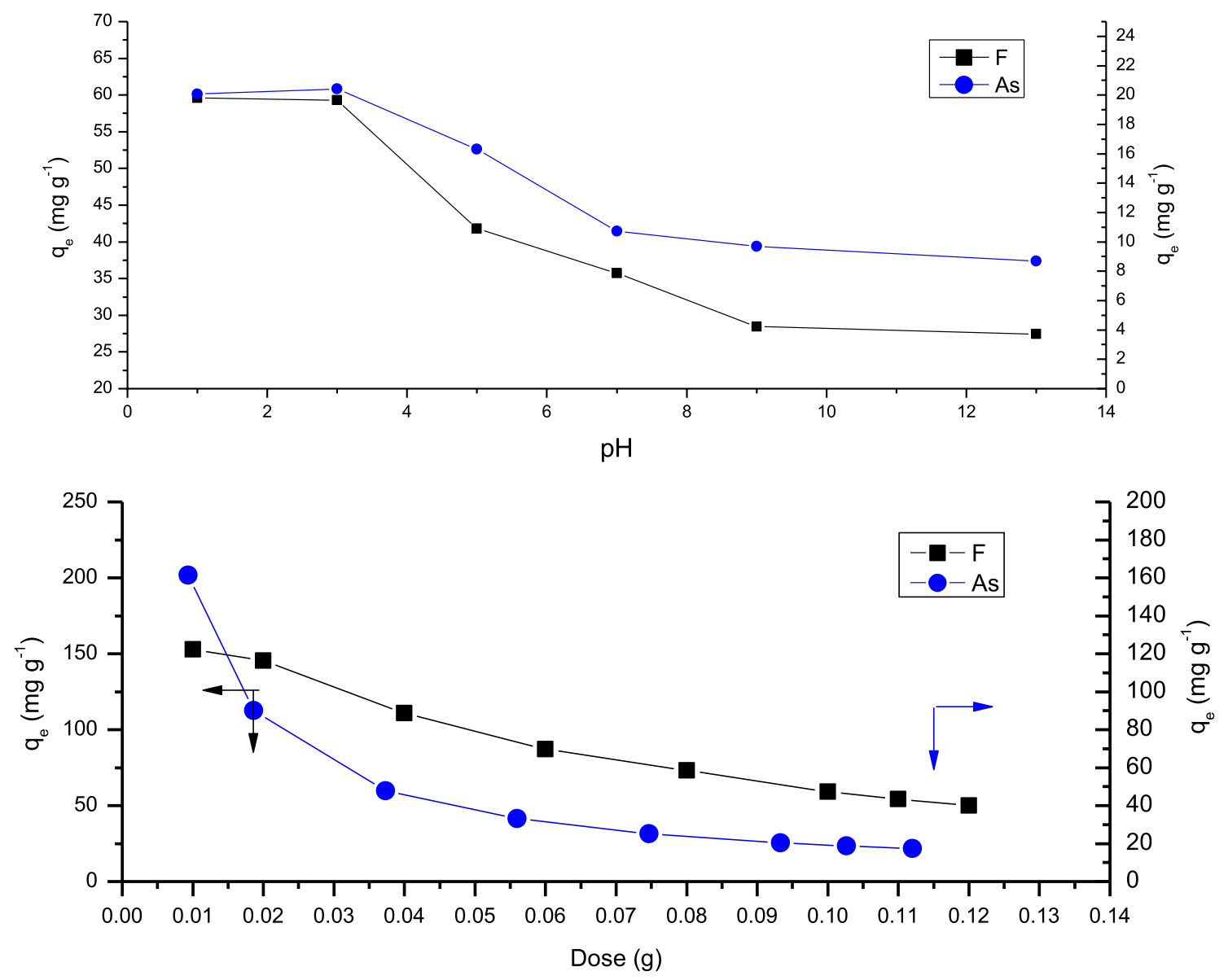

Fig. 8 Plots showing effect of pH and adsorbent dose on adsorption capacity of Fe-KWC for fluoride (black-shaded square) and arsenic (blueshaded circle)

Fig. 9 Fitting of adsorption models for adsorption of fluoride (a) and Arsenic (b) on Fe-KWC

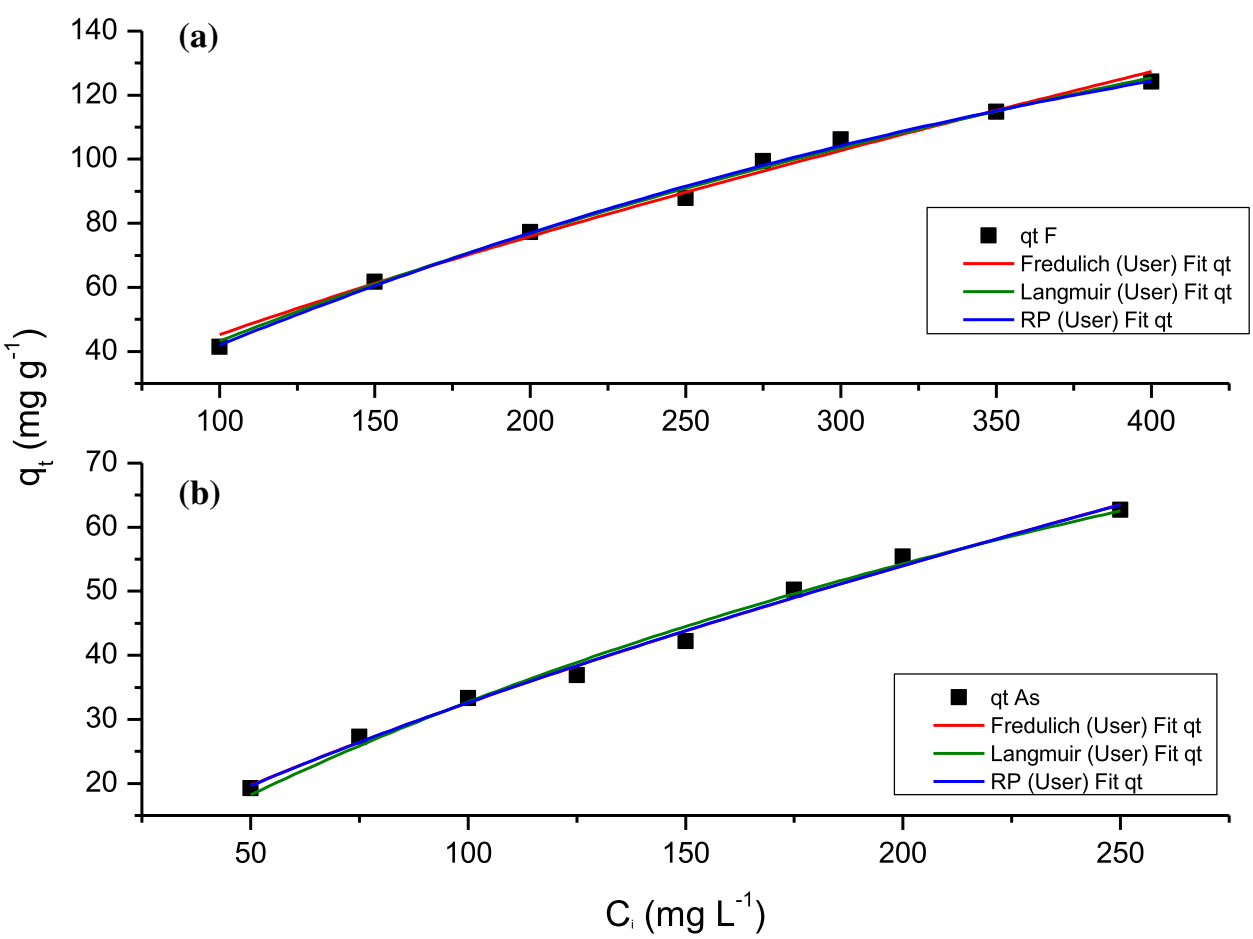


Table 6 Langmuir, Freundlich and R-P adsorption models constant as applied to Fluoride and arsenic adsorption on Fe-KWC

\begin{tabular}{lllc}
\hline Model & Parameter & Value (F) & Value (As) \\
\hline Langmuir & $K_{L}\left(\mathrm{~L} \mathrm{mg}^{-1}\right)$ & 0.001 & 0.003 \\
& $q_{m}\left(\mathrm{mg} \mathrm{g}^{-1}\right)$ & 342.79 & 159.49 \\
& $R_{\text {adj }}^{2}$ & 0.994 & 0.989 \\
& $S D\left(\mathrm{mg} \mathrm{g}^{-1}\right)$ & 2.050 & 1.555 \\
Freundlich & Reduced $\chi^{2}$ & 4.203 & 2.418 \\
& $K_{F}\left(\mathrm{mg} \mathrm{g}^{-1}(\mathrm{mg}\right.$ & 1.452 & 1.139 \\
& $\left.\left.\mathrm{~L}^{-1}\right)^{-1 / \mathrm{nF}}\right)$ & & \\
& $n_{\mathrm{F}}$ & 1.339 & 1.373 \\
& $R_{\text {adj }}^{2}$ & 0.989 & 0.992 \\
& $S D\left(\mathrm{mg} \mathrm{g}^{-1}\right)$ & 2.921 & 1.309 \\
R-P & Reduced $\chi^{2}$ & 8.535 & 1.714 \\
& $K_{R P}\left(\mathrm{~L} \mathrm{~g}^{-1}\right)$ & 0.441 & 3.372 \\
& $a_{R P}\left(\mathrm{mg} \mathrm{L}^{-1}\right)$ & $4.6 \times 10^{-5}$ & 2.361 \\
& $G$ & 1.52 & 0.299 \\
& $R_{\text {adj }}^{2}$ & 0.995 & 0.990 \\
& $S D\left(\mathrm{mg} \mathrm{g}^{-1}\right)$ & 2.044 & 1.434 \\
& Reduced $\chi^{2}$ & 4.180 & 2.056 \\
\hline
\end{tabular}

\section{Water samples analysis and their adsorption studies}

After optimization of experimental parameters (time: $30 \mathrm{~min}, \mathrm{pH}: 3$; temperature: $40{ }^{\circ} \mathrm{C}$, dose: $0.1 \mathrm{~g}$, concentration: $100 \mathrm{mg} \mathrm{L}^{-1}$ ), actual drinking water samples which exceeded MCL were subjected to treatment with Fe-KWC. The results of which are given in Fig. 10. Results, with the exception of few samples, indicate a high percentage removal for both $\mathrm{F}^{-}$and $\mathrm{As}^{3 / 5+}$. It can be observed that in all the samples the percentage removal for $\mathrm{F}^{-}$falls between 81 and $100 \%$ while for $\mathrm{As}^{3 / 5+}$ removal efficiency varied between 13 and $100 \%$.

Whereas work by Rathore et al. (2017) using aluminum oxide/ hydroxide nano-adsorbents exhibited a higher, i.e.,
98.6 percent removal efficiency of arsenic (initial concentration As: $512 \mu \mathrm{g} \mathrm{L}^{-1}$ while final concentration after treatment was $7 \mu \mathrm{g} \mathrm{L}^{-1}$ ). Whereas, $\mathrm{F}^{-}$removal efficiency was observed to be $83.3 \%\left(6300-1000 \mu \mathrm{g} \mathrm{L}^{-1}\right)$ from real water samples under optimum conditions (i.e., $\mathrm{pH}=7$, adsorbent dose $=8 \mathrm{~g} \mathrm{~L}^{-1}$ and contact time $=300 \mathrm{~min}$ ). In another similar undertaking, mesoporous alumina and $\mathrm{Ca}$ doped alumina exhibited selective outstanding defluoridation capacities up to $450 \mathrm{mg} \mathrm{g}^{-1}$ while arsenic removal efficiency reached above 90 percent (Li et al. 2011).

To statistically validate between the pre- and posttreatment concentrations of $\mathrm{As}^{3+}$ and $\mathrm{F}^{-}$, an independent sample $t$ test was carried out using IBM SPSS version 20. Based on the results, it can be stated that there was a significant difference in mean $\mathrm{As}^{3+}$ and $\mathrm{F}^{-}$values before and after treatment $\left(t_{28.791}=3.067, p<0.001\right.$ for $\mathrm{As}^{3+}$ and $t_{27.008}=1.913, p<0.05$ for $\mathrm{F}^{-}$). The average $\mathrm{As}^{3+}$ concentration after treatment was 27.357 units lesser than the average concentration before treatment, while average concentration of $\mathrm{F}^{-}$after treatment was 31.036 units lesser as compared to the average concentration before treatment (Supplementary data Table S2).

\section{Conclusion}

Fe-KWC nano-adsorbent offers a two-way approach toward safe environment. Firstly, it reduces impacts of $\mathrm{As}^{3+}$ and $\mathrm{F}^{-}$on human health by removal of excessive arsenic and fluoride from drinking water. Secondly, FeKWC nano-adsorbent is user friendly, non-corrosive, less soluble, reusable and easy to handle which makes it safe to environment. Fe-KWC due to its small particle size has high capacity for removal of $\mathrm{As}^{3+}$ and $\mathrm{F}^{1-}$. The method used in this study for removal of arsenic and fluoride from

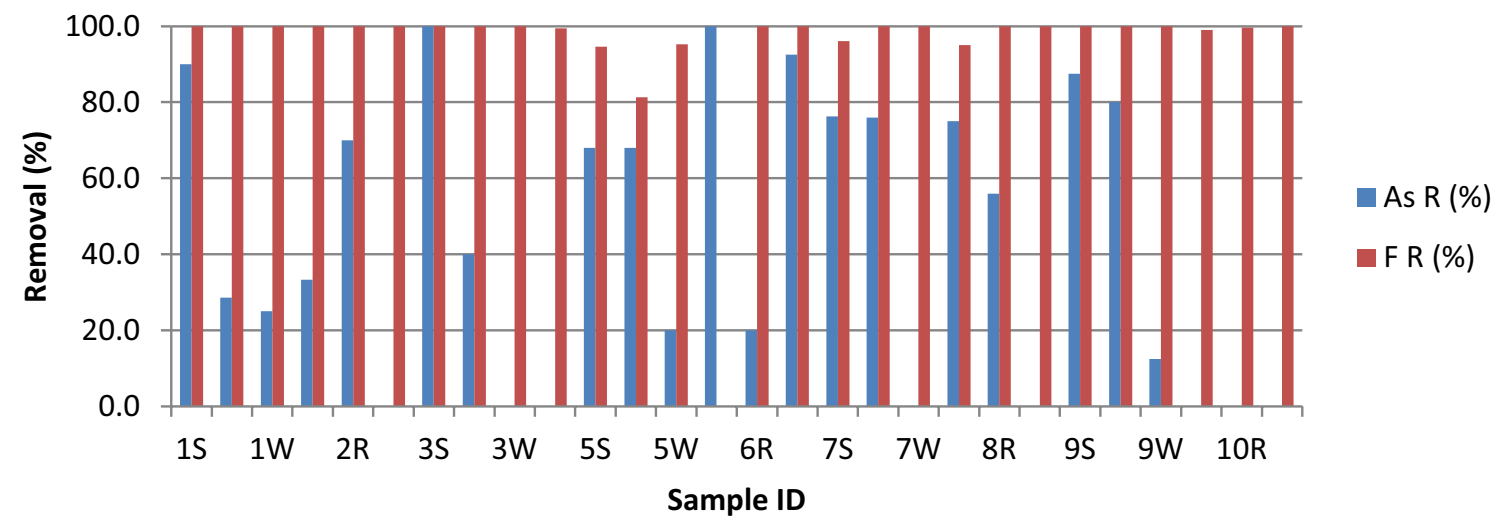

Fig. 10 Removal percentage of Fluoride and Arsenic after treatment of real water samples with Fe-KWC 
drinking water is simple, less time consuming and can be used for treatment of water in Pakistan.

Supplementary Information The online version contains supplementary material available at https://doi.org/10.1007/s13201-021-01531-0.

Acknowledgements The authors would like to acknowledge Mr. Ghulam Mohyuddin, Lecturer (Remote Sensing/GIS), University of Veterinary and Animal Sciences, Lahore for his help in preparation of manuscript.

Funding The author(s) received no specific funding for this work.

\section{Declarations}

Conflict of interest The authors have no conflict of interest to declare.

Open Access This article is licensed under a Creative Commons Attribution 4.0 International License, which permits use, sharing, adaptation, distribution and reproduction in any medium or format, as long as you give appropriate credit to the original author(s) and the source, provide a link to the Creative Commons licence, and indicate if changes were made. The images or other third party material in this article are included in the article's Creative Commons licence, unless indicated otherwise in a credit line to the material. If material is not included in the article's Creative Commons licence and your intended use is not permitted by statutory regulation or exceeds the permitted use, you will need to obtain permission directly from the copyright holder. To view a copy of this licence, visit http://creativecommons.org/licenses/by/4.0/.

\section{References}

Azizian S (2004) Kinetic models of sorption: a theoretical analysis. J Colloid Interface Sci 276(1):47-52

Batool F, Akbar J, Iqbal S, Noreen S, Bukhari SNA (2018) Study of isothermal, kinetic, and thermodynamic parameters for adsorption of cadmium: an overview of linear and nonlinear approach and error analysis. Bioinorg Chem Appl 2018:1-11

Brahman KD, Kazi TG, Baig JA, Afridi HI, Khan A, Arain SS, Arain MB (2014) Fluoride and arsenic exposure through water and grain crops in Nagarparkar, Pakistan. Chemosphere 100:182-189

Butt RS, Nazir R, Khan MN, Hamid A, Deeba F (2014) Treatment of electroplating industry wastewater using iron nanoparticle doped spent tea waste charcoal. J Biodivers Environ Sci 5:7-17

Darwish AAA, Rashad M, Al-Aoh HA (2019) Methyl orange adsorption comparison on nanoparticles: isotherm, kinetics, and thermodynamic studies. Dyes Pigments 160:563-571

De Jesús RBA, Simón Yobanny RL, María de Lourdes MS et al (2019) Eco-friendly synthesis of Fe3O4 nanoparticles: evaluation of their catalytic activity in methylene blue degradation by kinetic adsorption models. Results Phys 12:989-995

Farooqi A, Masuda H, Firdous N (2007) Toxic fluoride and arsenic contaminated water in Lahore and Kasur districts, Punjab, Pakistan and possible contaminant sources. Environ Pollut 145(3):839-49

Farooqi A, Masuda H, Siddiqui R, Naseem M (2009) Sources of arsenic and fluoride in highly contaminated soils causing groundwater contamination in Punjab, Pakistan. Arch Environ Contam Toxicol 56:693-706

Greenman DW, Bennett GD, Swarzenski WV (1967) Ground-water hydrology of the Punjab, West Pakistan, with emphasis on problems caused by canal irrigation. US Government Printing Office; 1967.https://pubs.usgs.gov/wsp/1608h/report.pdf

Guo H, Yang L, Zhou X (2014) Simultaneous removal of fluoride and arsenic from aqueous solution using activated red mud. Sep Sci Technol 49(15):2412-2425

Hammud KK et al (2016) New chemically prepared-waste cooked tea based activated carbon: FTIR, XRD, AFM, and SEM spectroscopic studies. Int J Res Pharmacy Chem 6:220-229

Jagtap S, Yenkie MK, Labhsetwar N, Rayalu S (2012) Fluoride in drinking water and defluoridation of water. Chem Rev 112(4):2454-2466

Jiang S, Su J, Yao S, Zhang Y, Cao F, Wang F et al (2014) Fluoride and arsenic exposure impairs learning and memory and decreases mGluR5 expression in the hippocampus and cortex in rats. PLoS One 9(4):e96041. https://doi.org/10.1371/journal.pone.0096041

Korai MS, Ali M, Lei C, Mahar RB, Yue D (2020) Comparison of MSW management practices in Pakistan and China. J Mater Cycles Waste Manage 1:1-1

Kumar V, Talreja N, Deva D, Sankararamakrishnan N, Sharma A, Verma N (2011) Development of bi-metal doped micro-and nano multi-functional polymeric adsorbents for the removal of fluoride and arsenic (V) from wastewater. Desalination 282:27-38

Li W, Cao CY, Wu LY, Ge MF, Song WG (2011) Superb fluoride and arsenic removal performance of highly ordered mesoporous aluminas. J Hazard Mater 198:143-150

Li R, Chen S, Li X, Saifullah Lar J, He Y, Zhu B (2009) Anaerobic codigestion of kitchen waste with cattle manure for biogas production. Energy Fuels 23(4):2225-2228

Lima ÉC, Adebayo MA, Machado FM (2015) Kinetic and equilibrium models of adsorption. In: Bergmann CP, Machado FM (eds) Carbon nanomaterials as adsorbents for environmental and biological applications. Springer, Cham, pp 33-69

Malik AH, Khan ZM, Mahmood Q, Nasreen S, Bhatti ZA (2009) Perspectives of low cost arsenic remediation of drinking water in Pakistan and other countries. J Hazard Mater 168:1-12

Mazhar I, Hamid A, Afzal S (2019) Groundwater quality assessment and human health risks in Gujranwala District. Pakistan Environ Earth Sci 78:634. https://doi.org/10.1007/s12665-019-8644-y

Murtaza G, Habib R, Shan A, Sardar K, Rasool F, Javeed T (2017) Municipal solid waste and its relation with groundwater contamination in Multan. Pakistan IJAR 3(4):434-441

Qasim M, Ali Jakhrani M (2018) Physicochemical and elemental contamination assessment in groundwater samples of Khairpur Mirs, Pakistan. Hum Ecol Risk Assess Int J 24(4):870-885. https://doi. org/10.1080/10807039.2016.1277415

Qian L, Zhang W, Yan J, Han L, Chen Y, Ouyang D, Chen M (2017) Nanoscale zero-valent iron supported by biochars produced at different temperatures: synthesis mechanism and effect on $\mathrm{Cr}$ (VI) removal. Environ Pollut 1(223):153-160

Randhawa MA, Ahmad G, Anjum FM, Asghar A, Sajid MW (2014) Heavy metal contents and their daily intake in vegetables under peri-urban farming system of Multan, Pakistan. Pak J Agric Sci $51(4)$

Rasool A, Farooqi A, Xiao T, Masood S, Kamran MA (2016) Elevated levels of arsenic and trace metals in drinking water of Tehsil Mailsi, Punjab, Pakistan. J Geochem Explor 169:89-99

Rathore VK, Mondal P (2017) Competitive Adsorption of arsenic and fluoride onto economically prepared aluminum oxide/hydroxide nanoparticles: multicomponent isotherms and spent adsorbent management. Ind Eng Chem Res 56:8081-8094

Ritchie H, Roser M (2018) Water access, resources \& sanitation. OurWorldInData.org. 10:2018 https://ourworldindata.org/water-acces sresources-sanitation

Rodríguez-Pérez J, Lopez-Anton MA, Díaz-Somoano M, García R, Martinez-Tarazona MR (2011) development of gold 
nanoparticle-doped activated carbon sorbent for elemental mercury. Energy Fuels 25:2022-2027

Sahoo TR, Prelot B (2020) Adsorption processes for the removal of contaminants from wastewater: the perspective role of nanomaterials and nanotechnology. Nanomaterials for the detection and removal of wastewater pollutants. Elsevier, Amsterdam, pp $161-222$

Shi LN, Zhang X, Chen ZL (2011) Removal of chromium (VI) from wastewater using bentonite-supported nanoscale zero-valent iron. Water Res 45(2):886-892

Singhal RK, Gangadhar B, Hirakendu B et al (2012) Remediation of malathion contaminated soil using zero valent iron nano-particles. Am J Anal Chem 3:76

Srivastava SK, Senapati S, Singh SB, Raul PK (2016) Magnetic Ni/ PPy nanocomposite as effective reusable adsorbent for removal of arsenite and fluoride from contaminated water. RSC Adv 6:113424-113431

Sun YP, Li XQ, Cao J, Zhang WX, Wang HP (2006) Characterization of zero-valent iron nanoparticles. Adv Colloid Interface Sci 120(1-3):47-56

Tang Y, Wang J, Gao NY (2010) Characteristics and model studies for fluoride and arsenic adsorption on goethite. J Environ Sci 22:1689-1694

Yu F, Steele PH, Ruan R (2010) Microwave pyrolysis of corn cob and characteristics of the pyrolytic chars. Energy Sources, Part a: Recovery, Utilization Environ Effects 32(5):475-484
World Health Organization (2004) Flouride in drinking-water background document for development of WHO guidelines for drinking-water quality WHO/SDE/WSH/03.04/96 https://www.who. int/water_sanitation_health/dwq/chemicals/fluoride.pdf

World Health Organization (2011) Arsenic in drinking-water background document for development of WHO guidelines for drinking-water quality, WHO/SDE/WSH/03.04/75/Rev/1 https://www. who.int/water_sanitation_health/dwq/chemicals/arsenic.pdf).

World Health Organization (2017) Guidelines for drinking-water quality fourth edition incorporating the first addendum

Xie Z, Guan W, Ji F, Song Z, Zhao Y (2014) Production of biologically activated carbon from orange peel and landfill leachate subsequent treatment technology. J Chem. https://doi.org/10.1155/ 2014/491912)

Yu Q, Li H (2020) Moderate separation of household kitchen waste towards global optimization of municipal solid waste management. J Clean Prod 277:123330

Zeng Qi-bing Xu, Xian Y-Y et al (2014) The combined effects of fluorine and arsenic on renal function in a Chinese population. Toxicol Res 3:359-366

Publisher's Note Springer Nature remains neutral with regard to jurisdictional claims in published maps and institutional affiliations. 